Journal of Economics and Behavioral Studies

Vol. 4, No. 3, pp. 163-171, Mar 2012 (ISSN: 2220-6140)

\title{
Does Human Capital Expedite Economic Development? The Case of Pakistan
}

\author{
Muhammad Tahir Mahmood1, *Kashif-ur-Rehman² \\ ${ }^{1}$ Foundation University Islamabad, Pakistan \\ 2Iqra University, Islamabad, Pakistan \\ *drkashif@iqraisb.edu.pk
}

\begin{abstract}
The population merely is not a guarantee of the economic development of a country. The human capital increases the productivity of the workforce and develops the good working environment characterized by commitment and motivation. The low level of the human capital is viewed as one of the factors that may hinder the process of economic development in low developed countries. This conjecture seems working in Pakistan. This study is an endeavor to examine how human capital influences the economic development of Pakistan by using the time series data for the period (1971-2009). For the data analysis, the bound testing approach to co integration within the framework of the Autoregressive Distributed Lag (ARDL) was used. The empirical results of all the proxies of human capital except 'expenditure on education' supported the hypothesis.
\end{abstract}

Keywords: Human Capital; Economic Development; Foreign Direct Investment; Domestic Investment, Pakistan

\section{Introduction}

The link of human capital with economic development can be traced from the literature not only at the country level data, but also in cross-country studies. The human capital is considered as a prerequisite for economic development. For the growth in developing countries, accumulation of human capital is as much necessary as that of physical capital. The human capital can play a vital role in the economic development by increasing the productivity of the workforce. The underdeveloped countries generally lack the critical skills and abilities required by the industrial sector and have a surplus workforce. The human capital formation can solve this problem by developing the required skills and abilities. The human capital enhancement can be expected to contribute to developing the good working environment duly characterized by the commitment and the motivation indirectly. The importance of the human capital regarding the economic development and the indirect social impact on the host country is well documented in the literature. Adam Smith included the abilities of all the inhabitants in the fixed capital stock of a country. Marshal regarded the expenditure on the education as the national investment and the most valuable capital. It is the lack of investment in the human capital that impedes the growth in the under-developed countries (UDCs) (Lekhi, 2008). When we consider the condition of the human capital in Pakistan, it looks much feeble. Taking the level of education as a proxy for the human capital, the literacy rate in Pakistan was $53 \%$ that was too low as compared to those of in other countries in the region. The net enrolment rate (NER) for the primary school in Pakistan was $52 \%$ (Government of Pakistan, 2006), while the countries like Hong Kong, Singapore, India, Indonesia, Malaysia, Thailand and Korea had NER more than 85\% (UNDP, 2005). Therefore, this too low NER in Pakistan painted a blurring picture of the future trend of the human capital.

According to (Government of Pakistan, 2006) Pakistan was spending $2.1 \%$ of her GDP on the education sector which was too low as compared with that of in other Asian countries like Malaysia, Thailand, India, Hong Kong, and Korea where it had been 8.1, 5.2, 4.1, 4.4, and 4.2\% respectively during 2000-2002 (UNDP, 2005). Similarly, the gross percentage enrolment at the tertiary level of Pakistan in 2004 was 3.20 while in China, India, Thailand, and Republic of Korea it touched the figure 19.1, 11.76, 40.98 and 88.52 respectively (World Bank, 2007). The GNP per capita is considered as the one proxy for the measurement of the economic development. Its value in Pakistan during the period of 1971-2005 increased from \$170 to \$690 while during the same period; in Singapore, it changed from \$1070 to \$27580, in Hong Kong, it rose from \$ 1070 to \$ 27670 and in Malaysia, it went up from \$ 420 to \$ 4970. In Asia, Singapore, Hong Kong and Malaysia showed an enormous increase in the GNP per capita as compared to that of in Pakistan. The countries that 
enhanced the human capital also excelled in the economic development. The above grim picture of facts about the human capital and the GNP per capita in Pakistan openly speaks of this situation. This nexus also looks to be on in Pakistan as the poor human capital might have contributed to the poor economic development. The purpose of this study is to investigate this very nexus empirically in Pakistan for the period (1971-2009). The previous studies regarding Pakistan are very limited and showed controversial results on this nexus. Moreover, this study differs from previous on temporal bases. The remaining sections of the paper contain the literature review regarding the theoretical and empirical evidence of impact of human capital on economic development; selection of explanatory variables; model formulation; estimation of model, and then empirical results and conclusion.

\section{Literature Review}

The human capital can play an important role in economic development. According to Simon Kuznets, the major capital stock of the industrially advanced countries was not the physical equipment; it was the body of the knowledge gathered from the discoveries of the empirical research work and capability of its population to use that knowledge effectively. Similarly, Prof. Galbraith said that a large part of the industrial growth was not achieved through the capital investment but from the investment on the people (Lekhi, 2008). The endogenous growth theories emerged in 1980s included the knowledge as a vital element of the capital. According to the many endogenous growth models, an important factor of the production contributing to a higher and sustained growth had been found to be the initial stock of the human capital and its accumulation rate. The proponents of the endogenous growth literature (Romer, 1990; Lucas, 1988; and Rebelo, 1991) conjectured that the human capital acted as a driving force for the technological progress and, consequently, led to the economic growth. The newly industrialized economies (NIEs) in East Asia transformed their economies from the agriculture-dominant economies to the modern industry-dominant economies through the technological development by human capital enhancement. In the NIEs, the government played a vital role in the human capital development. The East Asian countries like Malaysia, the Republic of Korea, and Thailand progressed very rapidly than the other South Asian countries like Pakistan and India and least developed countries of Asia like Bhutan, Nepal, Cambodia, and Bangladesh. The literature showed the significant role of the human capital in this development. According to Khan (2007b), the knowledge and the market driven skills were essential for achieving the highly sustainable economic growth. The slow socioeconomic progress in the South Asian countries stemmed from the low knowledge base; inadequate and irrelevant skills, and the use of obsolete technology. Iqbal and Zahid (1998) examined the effects of some key macroeconomic variables (including human capital) on the economic growth of Pakistan from 1959-60 to 1996-97. The results showed that the real GDP growth and the per capita real income growth were related positively to the primary school enrolment-labor force ratio (used as proxy of the human capital). The impact of the middle, high, and other enrolments was found insignificant with the coefficients having unexpectedly negative sign.

Benhabib and Spiegel (1994) using the cross country estimates of physical and human capital stocks indicated that the impact of the human capital on the per capita growth rates was insignificant, however, the growth rate of the total factor productivity was influenced positively by the nation's stock of the human capital. Grammy and Assane (1996) used different forms of the human capital investment to investigate the effects on the growth of the per capita income and found it significantly positive. Focusing on the endogenous growth theory, Dauda (2010) examined empirically the role of the human capital in the Nigeria's economic development. The results indicated that there existed indeed a long-run relationship between the human capital formation measured by the enrolment in educational institutions and the economic growth of Nigeria. The findings showed that there was a feedback mechanism between the human capital formation and the economic growth in Nigeria. Abbas (2001) studied empirically the impacts of the human capital on the economic growth of Pakistan and Sri Lanka. He found that the primary schooling enrolment rates had a negative while the secondary and the higher schooling enrolment rates had a positive and significant impact on the economic growth for both the countries in the sample. Odusola (1998) found that the human capital, measured by a continuing expenditure on education, was positively related to the growth in Nigeria though the relationship was not the robust one. Adamu (2003) investigated empirically the impact of the human capital formation on the economic growth in Nigeria during 1970 - 2000. He pointed out that the investment in the human capital in the form of education and training led to the economic growth for its impact on the 
labor productivity. From the study of 98 countries, Barro (1991) found that given the level of the initial per capita GDP, there was a positive relationship of the growth rate with the starting amount of the human capital. The poor countries having high human capital per person (in relation to their level of per capita GDP) tended to catch up with the rich countries, but not otherwise. The countries with the high human capital had the low fertility rates and high ratios of physical investment to GDP. Birdsall, Ross, and Sabot (1993) investigated the loss in the economic growth in Pakistan due to the low investment in education and especially in education of females. Their analysis suggested that if the female enrolment in the primary schools had been as high as male one in 1960 (46\%) instead of $13 \%$, per capita income of Pakistan would have been more than $15 \%$ greater than it had been then.

\section{Selection of Explanatory Variables and Model Formulation}

As the economies strived to transform themselves into the knowledge economies, hence, the value of the human capital increased. The expenditure on the human capital development began to be treated as the capital. The effects of the human capital on the economic development could be traced from the developing countries like Singapore, which used the human capital development as the core policy for the development. Dauda (2010) found the positive effect of the human capital on the economic development of Nigeria. Grammy \& Assane (1996) found the positive effect of the human capital on the per capita income. Iqbal \& Zahid (1998) found the mixed effects of the human capital on the growth in Pakistan. The model of this study was based on the endogenous growth theory and was derived from the production function following Makki and Sumwaru (2004), Balasubramanyam, Salisu, and Sapsford (1999), and Borensztein, De Gregorio, and Lee (1998). In this model, the change in per capita GNP as a proxy for the economic development was the dependent variable and the human capital; the FDI inflow, and the domestic investment were used as the independent variables. At the macroeconomic level, the FDI might play a vital role for enhancing the capital formation; generating revenue for the government through taxes, and defusing the pressure of the balance of payment (Seid, 2002). Shabbir and Mahmood (1992) analyzed the impact of the foreign private investment on the growth and found its significant positive impact on the growth rate of the GNP. Moreover, since the multinational corporations invest in a country following the strategies with the long time horizons and objectives and, once installed, have the large sunk costs in the host countries. The FDI is considered as the less volatile than the portfolio investment and other types of international financial flows. For both the reasons, an increasing volume of the FDI is often taken as a vital contribution to the development process. The physical capital and economic development association has the sufficient evidence in the theoretical and the empirical literature. In the growth theories, the domestic capital has been the central point of discussion. It is regarded as the engine for the long run sustained economic growth process. Atique, Ahmad and Azhar (2004), Iqbal \& Zahid. (1998), Makki \& Sumwaru (2004), and Sahoo (2006) found the positive impact of the domestic capital on the economic growth. The reason for using domestic capital and the foreign one separately is that the foreign capital is assumed to be utilized under the advanced technology and management as compared to domestic capital. As regards the impact of the human capital on the economic development, the following hypothesis was tested:

$\mathrm{H}$ : The human capital enhances the economic development of Pakistan

In order to test empirically this hypothesis, the researcher specified the following formulation:

$(G N P P C)_{t}=\alpha+\beta_{1}(H C)_{t}+\beta_{2}(F D I)_{t}+\beta_{3}(C H K)_{t}+\mu_{t}$

Where $\mu_{\mathrm{t}}$ is the stochastic error term capturing the left over effects. It is assumed to be distributed independently and normally with the zero mean and the constant variance. The (GNPPC) $t$ was the change in the per capita GNP and was used as the proxy for the economic development. Lekhi (2008) suggested the per capita GNP as the proxy for the measurement of the economic development for the developing countries. In the literature, the most commonly used proxies for measuring the human capital $(\mathrm{HC})_{t}$ were the educational enrolment ratios. Fung, Iizaka, and Siu (2004) used the Higher Education enrolment, Zhang (2001) used share of Secondary School Enrolment in the total population, and Noorbakhsh, Paloni, and Youssef (2001) used the Secondary and the Tertiary enrolment ratios. Following Iqbal \& Zahid (1998), the researcher used the High School Enrolment (HSE), and the Other Educational Institutional Enrolment (OSE) as a ratio to the total employed labor force (LF). The OSE consists of the enrolment like the secondary; the vocational; the art and science colleges; the professional colleges, and the universities. The study did not use the Primary and the 
Middle School Enrolment as in the existing literature the High School Enrolment was used as the threshold level. Regarding the definition of the human capital, the expenditure on the education as percentage of the GNP (EXED) was also included in its measurement. The variable (FDI) $t$ was the foreign direct investment inflow as percentage of the GDP. The FDI inflow was used rather than the stock as according to Root and Ahmed (1979), the data on the FDI inflow were less vulnerable to the book-value bias. On the other hand, the FDI stock was expressed in the book value without considering the inflation and the exchange rate fluctuation. The (CHK) $t$ was the change in the stock of the domestic investment as a ratio of the GDP. First, the domestic investment was differenced and then divided by the real GDP to find the change.

In equation (1) the variable $(\mathrm{HC})_{\mathrm{t}}$ would be replaced by its proxies i.e. (HSE) $)_{\mathrm{t}}(\mathrm{OSE})_{\mathrm{t}}$ and $(\mathrm{EXED})_{\mathrm{t}}$. As the number of the observations was small, all the proxies would not be used at a time in the model. Moreover, the $(\mathrm{HSE})_{\mathrm{t}}$ and the $(\mathrm{OSE})_{\mathrm{t}}$ were found highly correlated; therefore these two were used separately with the third proxy. Consequently the equation (1) would be replaced by following two equations:

$(\text { GNPPC })_{t}=\alpha+\beta_{1}(H S E)_{t}+\beta_{2}(E X E D)_{t}+\beta_{3}(F D I)_{t}+\beta_{4}(C H K)_{t}+\mu_{t}$

$(G N P P C)_{t}=\alpha+\beta_{1}(O S E)_{t}+\beta_{2}(E X E D)_{t}+\beta_{3}(F D I)_{t}+\beta_{4}(C H K)_{t}+\mu_{t}$

In this study we used the time series annual data on the relevant variables for the period (1971-2009). The dependent variable (GNPPC) $)_{t}$ and the independent variable $(\mathrm{FDI})_{\mathrm{t}}(\mathrm{CHK})_{\mathrm{t}}$, High School Enrolment $(\mathrm{HSE})_{\mathrm{t}}$, and the enrolment in other educational institutions (OSE) $t$ were collected from the State Bank of Pakistan (2005, 2010). The employed labor force (LF), and the expenditure on the education as percentage of the GNP (EXED)t were taken from the Government of Pakistan (1996, 2006, and 2010).

Estimation of the Model: To examine the relationship between the dependent and the independent variables, the bound testing approach to co integration within the framework of the Autoregressive Distributed Lag (ARDL) was used. This approach was developed by Pesaran, Shin and Smith (2001). It was then used by Khan (2007a) and Duasa (2007). The motives for employing this approach are: this technique is more appropriate for the small sample (from 30 to 80 observations) as in this study; this method employs only the single reduced form equation and does not require that the variables in the time series regression model are integrated of the order one and could be implemented regardless of as to whether the variables are I(0), I(1), or fractionally integrated; this method avoids the large number of specification to be made in the standard cointegration test, and it is also possible that different variables may have different optimal lags. An ARDL representation of the equation (2) was formulated as:

$$
\begin{aligned}
& \Delta \ln (G N P P C)_{t}=\alpha+\sum_{i=1}^{p} \phi_{i} \Delta \ln (G N P P C)_{t-i}+\sum_{i=0}^{p} \theta_{i} \Delta \ln (H S E)_{t-i}+\sum_{i=0}^{p} \lambda_{i} \Delta \ln (E X E D)_{t-i} \\
& +\sum_{i=0}^{p} \psi_{i} \Delta \ln (F D I)_{t-i}+\sum_{i=0}^{p} \gamma_{i} \Delta \ln (C H K)_{t-i}+\delta_{1} \ln (G N P P C)_{t-1}+\delta_{2} \ln (H S E)_{t-1} \\
& +\delta_{3} \ln (E X E D)_{t-1}+\delta_{4} \ln (F D I)_{t-1}+\delta_{5} \ln (C H K)_{t-1}+E_{t} \ldots \ldots \ldots \ldots \ldots \ldots \ldots \ldots \ldots \ldots
\end{aligned}
$$

Where $\Delta$ is the difference operator, $\varepsilon_{\mathrm{t}}$ is the random error. All these variables were in the logarithmic form. The Equation (4) estimated the impact of the human capital; the FDI inflow and stock of domestic investment on economic development of Pakistan. This relationship was tested by means of bound testing approach. To implement this technique a joint significance test was performed as:

$\mathrm{H}_{0}: \delta_{1}=\delta_{2}=\delta_{3}=\delta_{4}=\delta_{5}=0$ against the alternative hypothesis

$\mathrm{H}_{1}: \delta_{1} \neq \delta_{2} \neq \delta_{3} \neq \delta_{4} \neq \delta_{5} \neq 0$

The bound testing approach is based on F-statistic under the null hypothesis of no cointegration among the examined variables regardless of as to whether they are purely I(0) or I(1). Pesaran et al (2001) computed two sets of critical values for the given level of the significance. One set assumes that all the variables are I(0) referred to as lower bound and other set assumes that they are all I(1) referred to as upper bound. There are three options for further proceeding. If the computed F-statistic exceeds the upper critical bound value the $\mathrm{H}_{0}$ is rejected which implies that there exists the cointegration. If the F-statistic falls into the bounds, the test becomes inconclusive. And if the F-statistic lies below the lower critical bounds values, it means no cointegration. In the first case when the cointegration is found we shall estimate the long-run relationship 
and the short-run relationship by modifying the equation (4) into the equation (5) and equation (6) respectively.

$$
\begin{aligned}
& \ln (G N P P C) t=\alpha+\sum_{i=1}^{p} \phi_{i} \ln (G N P P C)_{t-i}+\sum_{i=0}^{p} \theta_{i} \ln (H S E)_{t-i}+\sum_{i=0}^{p} \lambda_{i} \ln (E X E D)_{t-i}+\sum_{i=0}^{p} \psi_{i} \ln (F D I)_{t-i} \\
& \left.+\sum_{i=0}^{p} \beta_{i} \ln (C H K)_{t-i}+\mu_{t} \quad \ldots \ldots \ldots \ldots \ldots \ldots . . .15\right)
\end{aligned}
$$

The order of the lags in the ARDL model was selected by Akaike Information Criterion (AIC) before the model was estimated by the ordinary least squares (OLS). For the annual data Pesaran and Shin (1999) recommended to choose a maximum of 2 lags.

$$
\begin{gathered}
\Delta \ln (G N P P C)_{t}=\alpha+\sum_{i=1}^{p} \phi_{i} \Delta \ln (G N P P C)_{t-i}+\sum_{i=0}^{p} \theta_{i} \Delta \ln (H S E)_{t-i}+\sum_{i=0}^{p} \lambda_{i} \Delta \ln (E X E D)_{t-i} \\
+\sum_{i=0}^{p} \psi_{i} \Delta \ln (F D I)_{t-i}+\sum_{i=0}^{p} \beta_{i} \Delta \ln (C H K)_{t-i}+\delta(E C M)_{t-1}+v_{t} \ldots \ldots \ldots \ldots . . .(6)
\end{gathered}
$$

where $(\mathrm{ECM})_{\mathrm{t}-1}$ was the error correction term which was the lagged value of the residual of the equation of the long-run relationship like equation (5) in this case.

By following the same technique, the ARDL representation of the equation (3) was as follows:

$$
\begin{gathered}
\Delta \ln (G N P P C)_{t}=\alpha+\sum_{i=1}^{p} \phi_{i} \Delta \ln (G N P P C)_{t-i}+\sum_{i=0}^{p} \theta_{i} \Delta \ln (O S E)_{t-i}+\sum_{i=0}^{p} \lambda_{i} \Delta \ln (E X E D)_{t-i} \\
+\sum_{i=0}^{p} \psi_{i} \Delta \ln (F D I)_{t-i}+\sum_{i=0}^{p} \gamma_{i} \Delta \ln (C H K)_{t-i}+\delta_{1} \ln (G N P P C)_{t-1}+\delta_{2} \ln (O S E)_{t-1} \\
+\delta_{3} \ln (E X E D)_{t-1}+\delta 4 \ln (F D I)_{t-1}+\delta_{5} \ln (C H K)_{t-1}+\varepsilon_{t} \ldots \ldots \ldots \ldots \ldots \ldots . . .
\end{gathered}
$$

The similar procedure (as used for equation 4 ) was adopted when the null hypothesis of no cointegration was tested for equation (7) and by following the pattern of equation (5) and equation (6) further long-run and short-run relationships were estimated for equation (7).

\section{Results}

In order to examine the influence of human capital on economic development of Pakistan, two equations (2) and (3) were formulated in the earlier section. Following Khan (2007a) and Duasa (2007) the bound testing approach to the cointegration with framework of Autoregressive Distributed Lag (ARDL) was used for the purpose. Before proceeding further, the order of integration of every variable included in these equations was checked by using the Augmented Dickey Fuller test for unit root. The result is reported in the following table.

\section{Table 1: Results of the Unit Root Test}

\begin{tabular}{lllll}
\hline Variables & Intercept/Trend & Level & First Difference & Decision \\
\hline GNPPC & I & 3.0725 & $-3.7035^{*}$ & I(1) \\
HSE & I & -1.0459 & $-3.4586^{* *}$ & I(1) \\
OSE & I & -0.5341 & $-4.2819^{*}$ & I(1) \\
EXED & I & -1.5708 & $-3.0465^{*}$ & I(1) \\
FDI & I & -1.8473 & $-4.9151^{*}$ & I(1) \\
CHK & I & $-4.0639^{*}$ & -- & I(0) \\
\hline
\end{tabular}

* Significant at the $1 \%$ level ** Significant at the $5 \%$ level *** Significant at the $10 \%$ level 
Since the variables were integrated of the mixed order like I(0) and I(1), hence ARDL approach was appropriate. Taking the equation (2), its ARDL formulation was equation (4). In order to estimate equation (4), the ordinary least square (OLS) was used with the software Eviews 3.1.

Table 2: Effect of Human Capital on Economic Development (HSE and EXED)

\begin{tabular}{|c|c|c|c|c|}
\hline \multicolumn{5}{|c|}{ Dependent Variable: DLOG(GNPPC) } \\
\hline \multicolumn{5}{|c|}{ Method: Least Squares } \\
\hline \multicolumn{5}{|c|}{ Sample: 19712009} \\
\hline \multicolumn{5}{|c|}{ Included observations: 35} \\
\hline \multicolumn{5}{|c|}{ Excluded observations: 4} \\
\hline Variable & Coefficient & Std. Error & t-Statistic & Prob. \\
\hline DLOG(GNPPC(-1)) & -0.095222 & 0.152783 & -0.623250 & 0.5390 \\
\hline DLOG(HSE) & 3.199912 & 1.220645 & 2.621493 & 0.0150 \\
\hline DLOG(EXED) & -1.076732 & 0.790515 & -1.362065 & 0.1858 \\
\hline DLOG(FDI) & 0.534442 & 0.177421 & 3.012277 & 0.0060 \\
\hline DLOG(CHK) & 0.406998 & 0.144388 & 2.818784 & 0.0095 \\
\hline LOG(GNPPC(-1)) & -0.391905 & 0.212185 & -1.846999 & 0.0771 \\
\hline LOG(HSE(-1)) & 0.376380 & 0.583687 & 0.644832 & 0.5252 \\
\hline LOG(EXED(-1)) & -1.030614 & 0.582593 & -1.769014 & 0.0896 \\
\hline LOG(FDI(-1)) & 0.552509 & 0.218732 & 2.525962 & 0.0185 \\
\hline LOG(CHK(-1)) & 0.268952 & 0.206109 & 1.304904 & 0.2043 \\
\hline $\mathrm{C}$ & 3.166081 & 1.408462 & 2.247900 & 0.0340 \\
\hline R-squared & 0.603209 & & & \\
\hline Adjusted R-squared & 0.437880 & & & \\
\hline Durbin-Watson stat & 2.298479 & & & \\
\hline F-statistic & 3.648527 & & & \\
\hline Prob(F-statistic) & 0.004527 & & & \\
\hline
\end{tabular}

The above table shows that the calculated value of F-statistic (3.64) is greater than the upper bound critical value (3.586 at $10 \%$ level of significance) suggested by Narayan (2004) for the small sample (between 30 to 80 observations). This implies that the null hypothesis of no cointegration cannot be accepted at $10 \%$ level of significance and, therefore, there is a cointegration relationship among the variables. Now, for the long-run relationship, equation (5) was estimated by the OLS. For the parsimonious purpose the most insignificant variables were excluded. The calculated value of the F-statistic (91.10) is greater than the upper bound of the critical value (5.966 at $1 \%$ level of significance) suggested by Narayan (2004). This implies that there exists long-run relationship. Then for the short run dynamics equation (6) was estimated. In this equation, the error correction term (ECM) $)_{t-1}$ is the lagged value of the residual of equation (5) of the long-run relationship. The results are reported in the following table.

Table 3: Short-run and Long-run Elasticity of GNPPC (by HSL and EXED)

\begin{tabular}{lll}
\hline Variable & Short-run Coefficient & Long-run Coefficient \\
\hline GNPPC(-1) & 0.163505 & $0.229905^{* * *}$ \\
HSE & $2.606192^{* *}$ & $1.477928^{*}$ \\
EXED & -0.672444 & -0.696411 \\
FDI & $0.307405^{* * *}$ & $0.581122^{*}$ \\
CHK & $0.324638^{*}$ & $0.384716^{*}$ \\
ECM $(-1)$ & $-0.779418^{* *}$ & \\
\hline
\end{tabular}

${ }^{*}$ Significant at the $1 \%$ level ${ }^{* *}$ Significant at the $5 \%$ level ${ }^{* * *}$ Significant at the $10 \%$ level

The results of the above table show that one proxy of the human capital i.e. the HSE has the significant positive impact on the GNPPC in the long-run as well as in the short-run, but the other proxy of the human capital i.e. the EXED showed surprisingly the contrary results. There might be various reasons for this. First of all, the general education is the main responsibility of the public sector in Pakistan and the efficiency of the public institutions is not satisfactory enough. The resources are wasted mercilessly due to the 
mismanagement of higher authorities of the department. Second, the politics involves in managerial decisions and the personal interest supercedes the country interest. Third, our institutions are producing such workforce as mostly has the general education rather than the professional and technical skills. Consequently, such workforce might not have contributed to enhance the economic development. Now it is the turn to estimate equation (7) which is the ARDL formulation of equation (3). The results of estimation of equation (7) are reported hereunder.

Table 4: Effect of Human Capital on Economic Development (OSE and EXED)

\begin{tabular}{|c|c|c|c|c|}
\hline \multicolumn{5}{|c|}{ Dependent Variable: DLOG(GNPPC) } \\
\hline \multicolumn{5}{|c|}{ Method: Least Squares } \\
\hline \multicolumn{5}{|c|}{ Sample: 19712009} \\
\hline \multicolumn{5}{|c|}{ Included observations: 35} \\
\hline \multicolumn{5}{|c|}{ Excluded observations: 4} \\
\hline Variable & Coefficient & Std. Error & t-Statistic & Prob. \\
\hline DLOG(GNPPC(-1)) & -0.268620 & 0.167223 & -1.606360 & 0.1213 \\
\hline DLOG(OSE) & 2.837514 & 1.399625 & 2.027339 & 0.0539 \\
\hline DLOG(EXED) & -1.724897 & 0.859293 & -2.007345 & 0.0561 \\
\hline DLOG(FDI) & 0.410817 & 0.191531 & 2.144914 & 0.0423 \\
\hline DLOG(CHK) & 0.487598 & 0.171348 & 2.845669 & 0.0089 \\
\hline LOG(GNPPC(-1)) & -0.519887 & 0.263122 & -1.975838 & 0.0598 \\
\hline $\operatorname{LOG}(\operatorname{OSE}(-1))$ & 0.921350 & 0.867622 & 1.061925 & 0.2988 \\
\hline LOG(EXED $(-1))$ & -1.162803 & 0.708722 & -1.640703 & 0.1139 \\
\hline LOG(FDI(-1)) & 0.524268 & 0.236131 & 2.220244 & 0.0361 \\
\hline LOG(CHK(-1)) & 0.386273 & 0.265629 & 1.454181 & 0.1588 \\
\hline $\mathrm{C}$ & 3.894296 & 1.797483 & 2.166527 & 0.0404 \\
\hline R-squared & 0.564197 & & & \\
\hline Adjusted R-squared & 0.382613 & & & \\
\hline Durbin-Watson stat & 2.083246 & & & \\
\hline F-statistic & 3.107080 & & & \\
\hline Prob(F-statistic) & 0.011089 & & & \\
\hline
\end{tabular}

From the above table the calculated value of the F-statistic is 3.10 which falls between the two critical bounds (2.67 as lower and 3.59 as upper at 10 percent level) set by Narayan (2004). This implies that the null hypothesis of no cointegration is inconclusive. When the residual of the above estimated model was tested for the unit root it was found stationary. It means that the variables were somewhat cointegrated. Now for the long- and short-run relationship, by changing the equation (7) on the pattern of equation (5) and equation (6) respectively, the estimated results are reported in the following table (7).

Table 5: Short-run and Long-run Elasticity of GNPPC (By OSE and EXED)

\begin{tabular}{lll}
\hline Variable & Short-run Coefficient & Long-run Coefficient \\
\hline GNPPC(-1) & 0.002170 & 0.170134 \\
OSE & $2.847930^{* *}$ & $1.957973^{*}$ \\
EXED & $-1.513446^{* *}$ & $-1.438416^{*}$ \\
FDI & 0.249300 & $0.577150^{*}$ \\
CHK & $0.393430^{*}$ & $0.452228^{*}$ \\
ECM $(-1)$ & $-0.830185^{* *}$ & \\
\hline * Significant at the 1\% level ** Significant at the 5\% level & *** Significant at the $10 \%$ level
\end{tabular}

* Significant at the $1 \%$ level ${ }^{* *}$ Significant at the $5 \%$ level ${ }^{* * *}$ Significant at the $10 \%$ level

The results in the above table show that one proxy of the human capital i.e. the OSE has the positive and significant effect on the economic development of Pakistan. The results of the second proxy i.e. the EXED are negative once again and matching with that of table 3. The results are consistent with that of Abbas (2001) regarding the effect of the high and the higher schooling enrolments on the economic development. The results of Iqbal \& Zahid. (1998) for Pakistan, however, are the contrary ones. The reason is the difference of the time period and the method of data analysis. From among the three proxies of the human capital two 
proxies i.e. HSE and OSE strongly support the hypothesis and justify the importance of the human capital for the economic development.

\section{Conclusion}

Mere population of a country is not a guarantee of the economic development. It is the human capital that increases the productivity of the workforce and develops the good working environment characterized by commitment and motivation. The lack of the investment in human capital is considered as one of the factors that may hinder the development in low developed countries. The countries which enhanced human capital also excelled in economic development. As the situation of the human capital in Pakistan is very poor so is the condition of the economic development. Is this nexus true for Pakistan? This study is an endeavor to examine this relationship empirically by using the time series data for the period (1971-2009). The previous studies in context of Pakistan are very limited and showed divergent results. This study would contribute to strengthen one view point. For the data analysis, the bound testing approach to cointegration within the framework of the Autoregressive Distributed Lag (ARDL) was used. The empirical results supported the hypothesis that human capital enhanced the economic development of Pakistan. The main proxies of the human capital (high school enrolment and other institutional enrolment e.g. secondary, vocational, colleges and universities) showed significantly positive impact on economic development. However, the third proxy (expenditure on education) depicted negative impact. From the findings it can be suggested that increase in enrolments at various level may expedite the economic development of Pakistan. The workforce can be utilized at optimum level for the steady economic development if it will be equipped with updated knowledge and skills. For further research there are vast areas regarding human capital and economic development. There are multiple ways to measure these two variables. By using different measures their relationships can be explored in terms of unidirectional as well as bidirectional. Moreover, interactive role of human capital with physical capital for economic development also demands investigation to make the utilization of sources optimum.

\section{References}

Abbas, Q. (2001). Endogenous Growth and Human Capital: A Comparative Study of Pakistan and Sri Lanka. The Pakistan Development Review, 40(4), 987-1007.

Adamu, P. A. (2003). The Impact of Human Capital Formation on Economic Development in Nigeria: An Error Correction Approach In.: Human Resource Development in Africa. Selected Papers for 2002 Annual Conference, Nigerian Economic Society, Ibadan, 53-78.

Atique, Z., Ahmad, M. H. \& Azhar, U. (2004). The Impact of FDI on Economic Growth Under Foreign Trade Regime: A Case Study of Pakistan. Pakistan Development Review, 43(4), 707-718.

Balasubramanyam, V. N., Salisu, M. \& Sapsford, D. (1999). Foreign Direct Investment as an Engine Of Growth. The Journal of International Trade and Economic Development, 8(1), 27-40.

Barro, R. J. (1991). Economic Growth in Cross Section of Countries. Quarterly Journal of Economics, 106(2), 407-443.

Benhabib, J. M. \& Spiegel, M. (1994). The Role of Human Capital in Economic Development: Evidence From Cross-Country Data. Journal of Monetary Economic, 34, 141-173.

Birdsall, N., Ross, D. \& Sabot, R. (1993). Underinvestment in Education: How Much Growth has Pakistan forgone? The Pakistan Development Review, 32(4), 453-499.

Borensztein, E., De-Gregorio, J. \& Lee, J. W. (1998). How Does Foreign Direct Investment Affect Economic Growth? Journal of International Economics, 45, 115-135.

Dauda, R. O. S. (2010). Role of Human Capital in Economic Development: An Empirical Study of Nigerian Case. 2010 Oxford Business \& Economics Conference Program. http://www.scribd.com/doc/37037464/Investment-in-Human-Resources-2

Duasa, J. (2007). Determinants of Malaysian Trade Balance: An ARDL Bound Testing Approach. Journal of Economic Cooperation, 28(3), 21-40.

Fung, K. C., Iizaka, H. \& Siu, A. (2004). Integrating the two Asian Economic Giants: Japanese Multinational Corporations in China. Journal of Asian Economics, 15, 957-975.

Government of Pakistan. (1996). Pakistan Economic Survey 1995-96. Economic Adviser's Wing, Finance Division, Government of Pakistan, Islamabad. 
Government of Pakistan. (2006). Pakistan Economic Survey 2005-06. Economic Adviser's Wing, Finance Division, Government of Pakistan, Islamabad.

Government of Pakistan. (2010). Pakistan Economic Survey 2009-10. Economic Adviser's Wing, Finance Division, Government of Pakistan, Islamabad.

Grammy, A. P. \& Assane, D. (1996). New Evidence on the Effect of Human Capital on Economic Growth. Applied Economic Letters, 4, 21-124.

Iqbal, Z. \& Zahid, G. M. (1998). Macroeconomic Determinants of Economic Growth in Pakistan. The Pakistan Development Review, 37(1), 125-148.

Khan, M. A. (2007a). Foreign Direct Investment and Economic Growth: The Role of Domestic Financial Sector. Pakistan Institute of Development Economics (PIDE) Working Paper 18.

Khan, M. A. (2007b). Role of Human Capital in Attracting Foreign Direct Investment: A South Asian Perspective. SAARC Journal of Human Resource Development 2007.

Lekhi, R. K. (2008). The Economics of Development and Planning. New Delhi, India, Kalyani Publishers..

Lucas, R. E. J. (1988). On the Mechanics of Economic Development. Journal of Monetary Economics, 22(1), 342.

Makki, S. S. \& Sumwaru, A. (2004). Impact of Foreign Direct Investment and Trade on Economic Growth: Evidence From Developing Countries. American Journal of Agriculture Economics, 86(3), 795-801.

Narayan, P. K. (2004). Reformulating Critical Values for the Bounds F-statistics Approach to Cointegration: An Application to the Tourism Demand Model for Fiji. Discussion Papers, Department of Economics, Monash University, Australia.

Noorbakhsh, F., Paloni, A., \& Youssef, A. (2001). Human Capital and FDI Inflows to Developing Countries: New Empirical Evidence. World Development, 29(9),1593-1610.

Odusola, A.F. (1998), Human Capital Investment and the Empirics of Economic Growth in Nigeria. In.: Rekindling Investment for Economic Development in Nigeria. Selected Papers for 1998 NES Annual Conference, Nigerian Economic Society, Ibadan, 257-272.

Pesaran, M. H., Shin, Y. (1999). Autoregressive Distributed Lag Modeling Approach to Cointegration Analysis, Chapter 11, in: Storm, S., (ed.), Econometrics and Economic Theory in the $20^{\text {th }}$ Century: The Ragnar Frisch Centennial Symposium (Cambridge: Cambridge University Press).

Pesaran, M. H., Shin, Y., \& Smith, R. J. (2001). Bound Testing Approaches to the Analysis of the Long run Relationships. Journal of Applied Economic, 16, 289-326.

Rebelo, S. (1991). Long-run Policy Analysis and Long-run Growth. Journal of Political Economy, 96, 500-521.

Romer, P. (1990). Endogenous Technological Change. Journal of Political Economy, 98(5), S71-102.

Root, F. \& Ahmed, A. (1979). Empirical Determinants of Manufacturing Direct Foreign Investment in Developing Countries. Economic Development and Cultural Change, 27, 751-767.

Sahoo, P. (2006). Foreign Direct Investment in South Asia: Policy, Trends, Impact and Determinants. ADB Institute Discussion Paper, 56.

Seid, S. H. (2002). Global Regulations of Foreign Direct Investment. 131 Main Street Burlington, VT 054015600 USA, Ashgate Publishing Company.

Shabbir, T. \& Mahmood, A. (1992). The Effects of Foreign Private Investment on Economic Growth of Pakistan. The Pakistan Development Review, 31(4), 831-841.

State Bank of Pakistan. (2005). Handbook of Statistics on Pakistan Economy 2005. http://www.sbp.gov.pk State Bank of Pakistan. (2010). Handbook of Statistics on Pakistan Economy 2010. http://www.sbp.gov.pk UNDP (2005). Human Development Report 2005: International Corporation at a Crossroads. New York: UNDP World Bank (2007). World development indicators 2007. CD-ROM, Washington, D.C. World Bank.

Zhang, K. H. (2001). How Does Foreign Direct Investment Affect Economic Growth in China? Economics of Transition, 9(3), 679-693. 